\title{
An Analysis of the Indonesian Government Policy on the Lockdown from the perspective of Human Rights
}

\author{
Andryan $^{1 *}$, Farid Wajdi ${ }^{1}$, Benito Asdhie Kodiyat ${ }^{1}$, Taufik Hidayat Lubis ${ }^{1}$ \\ ${ }^{1}$ University of Muhammadiyah Sumatera Utara, Medan, Indonesia \\ *Corresponding author. Email: andryan@umsu.ac.id
}

\begin{abstract}
Corona Virus Disease 2019 (Covid-19), has become a deadly threat in countries of the world, including Indonesia. As a rule of law, Indonesia regulates matters of emergency which are synonymous with the term state of emergency. To deal with the spread of Covid-19, the Indonesian government has issued some policies policies, including the temporary closure of public spaces (lockdown). The lockdown policy is not only an effort to prevent more widespread transmission, but has the potential to reduce the right to freedom of assembly. The right to freedom of assembly and movement from one place to another is part of the constitutional rights guaranteed by the state. This paper is intended to seek a constitutional policy formulation in the perspective of Human Rights in a Modern Legal State. This research uses normative juridical research. The approach to the problem used in this study includes a statutory approach and a conceptual approach. The data obtained were collected and analyzed qualitatively with a descriptive-analytical model, so that the results could be described comprehensively and systematically. As a form of realizing welfare for the people even in an emergency, the state must always actively take the initiative to act. This is as stated in Article 28A of the The 1945 Constitution of the Republic of Indonesia, "Everyone has the right to live and has the right to defend his life and life". The government must be able to make policies on handling Covid-19 from a human rights perspective. In the human rights context, there are at least 6 principles and guidelines on how to limit, delay and reduce the enjoyment of human rights. First, the determination must be based on law. Second, statements, notifications and emergency stops. Third, do not limit nonderogable rights. Fourth, it is really needed. Fifth, the arrangement is clear, strict, and does not have multiple interpretations. Six, emphasizes proportionality. The lockdown policy that prevents the people from fulfilling their daily needs, must be accompanied by policies that provide relief for the people, provide direct life insurance for all, policies to study / work at home without causing additional burdens for the family. As a modern constitutional state, one of its characteristics is the fulfillment of human rights based on the constitution. As a rule of law, the government must comply with regulations without having to make new regulations on lockdown policies, where the government must ensure the fulfillment of the basic needs of citizens and livestock feed as regulated in Article 55 paragraph (1) of Law No.6 of 2018 on Health Quarantine and ensure the quality of education and the reach of educational services that allow students to learn from home.
\end{abstract}

Keywords: Policy, Lockdown, Human Rights, Modern Rule of Law.

\section{INTRODUCTION}

In the context of a country that is threatened by an outbreak of an infectious disease that has become a global pandemic, namely Corona Virus Disease 19 (Covid-19), various efforts have been made by the government. Several countries in the world affected by the Covid-19 pandemic have declared an emergency status by temporarily closing public spaces and going in and out (lockdown). Facing threats to the safety of the nation and state, it is very urgent to stipulate a state of emergency. Determination of a state of emergency becomes an important matter, especially regarding the protection of the constitutional rights of citizens.

As head the head of state and head of government, the president of the Republic of Indonesia has strong legitimacy for the policy in 
determining the state of emergency status. This is also increasingly emphasized in the 1945 Constitution of the Republic of Indonesia which states that the Indonesian state is a Unitary State in the form of a Republic. In accordance with the provisions of Article 4 paragraph (1) of the 1945 Constitution, in running the government it is stated that the President of the Republic of Indonesia holds the power of government. The principle of the unitary state is the holder of the highest power over all State affairs, is the central government without any delegation or delegation of authority to regional governments or government affairs are not divided between the central government and regional governments, so that State affairs in the unitary State remain the holder of power. the highest in the State is the central government.[1]

In the running the state or government, things that are not normal often occur in managing the life of the state, where the legal system that is usually used is unable to accommodate the interests of the state or society so that it requires separate arrangements to move the functions of the state so that it can run effectively in order to guarantee respect. to the state and the fulfillment of the basic rights of citizens. Thus, the use of ordinary legal instruments from the beginning must anticipate various possible situations that are abnormal in nature so that the state can guarantee the survival of the nation and state.

As a law-based country, Indonesia has legal rules that serve as an umbrella for implementing emergencies. Law Number 74 of 1957 distinguishes a state of danger into two, namely a state of emergency and a state of war. Meanwhile, Perpu Number 23 of 1959 distinguishes the level of danger into three, namely the level of civil emergency, military emergency and state of war. Since the end of 1959 until now, the legal basis for implementing the state of emergency is the Perpu No. 23 of 1959. Meanwhile, the latest regulations regarding the status of an emergency, namely Law No.24 of 2007 concerning Disaster Management and Law No.6 of 2018 concerning Health Quarantine.

The state is an important entity in fulfilling the human rights of citizens even in emergencies and situations of danger. This is because the fulfillment of citizens' rights is the responsibility of the state as a result of the duty to respect, protect and fulfill these human rights. As reflected in the fourth Alenia paragraph of the 1945 Constitution, states that "Then rather than that, to form an Indonesian state government that protects the entire Indonesian nation and all Indonesian blood. The preamble to the 1945 Constitution, not only becomes the foundation in forming a state government, but also contains the ideals and goals of an independent country. Therefore, it becomes an obligation for the state to protect its people in any condition and condition.

If there is a violation of human rights, it is the duty of the state to restore that right. Such violations can be in the form of negligence (state) itself or failure to take adequate steps under certain conditions. The state's obligations in the 1945 Constitution are regulated expressis verbis in Article 28I paragraph (4) that the protection, advancement, enforcement and fulfillment of human rights are the responsibility of the state, especially the government.[2]

The Central Government sets policies in handling the Covid-19 disease outbreak with LargeScale Social Restrictions (PSBB) or Physical Distancing which is followed by the final stage of a Civil Emergency. The policy, considered by many to be a policy of disorientation. This is because the Civil Emergency in Perppu Number 23 of 1959 concerning Danger Conditions (Perppu on Hazards) which is the final stage in handling disease outbreaks, has an orientation in handling legal order and security in the context of a state of war emergency carried out by the security apparatus. So that the handling has a repressive orientation.

In the provisions of the Law on Health Quarantine which has the aim of preventing and preventing the entry and exit of diseases with the Health Quarantine mechanism. The regulation has an orientation by quarantine the area and is followed by the government's accountability in fulfilling the living needs of citizens whose areas are determined by Lockdown. Thus, the implementation of the PSBB policy and the final stages of Civil Emergency in the handling of the Covid-19 disease outbreak by the Central Government are considered enigmatic by suppressing the significance of cases through the Lockdown or Semi-Lockdown mechanism.

As a rule of law that is committed to protecting all and all blood spilled against its people, how should the state be present when deciding to make a lockdown policy. In fact, the lockdown policy may ignore human rights principles as reflected in the UN Charter on the fulfillment of civil rights. 


\section{RESEARCH METHOD}

This research uses normative juridical research. The problem approach used in this study includes a statute approach, a conceptual approach and a case approach. This research is a deductive study that describes legal events and legal consequences associated with the lockdown policy in the perspective of human rights in a modern rule of law. The data obtained were collected and analyzed qualitatively with a descriptive-analytical model. So that the results can be described comprehensively and systematically regarding the basis for consideration in establishing legal rules.

The discussion and analysis in the article aims to answer the problem formulation and research questions, show how the findings were obtained, explain the meaning of the research results, how the research results can solve problems and the possibility of their development. Discussion and analysis must answer the problem and research objectives.

\section{FINDINGS AND DISCUSSION}

\subsection{The Perspective of Law}

\subsubsection{Lockdown Policy}

Policy according to Thomas Dye (1981: 1), is whatever the government chooses to do or not to do. There are actions taken by the government regarding the interests of the public (the people). In David Easton's view, when the government makes public policy, at that time the government allocates values to society, because every policy contains a set of values in it. [3]

Menghadapi ancaman pandemi global, pemerintah In facing the global pandemic threats, the government has taken action by establishing a lockdown policy to prevent the massive spread of health disasters. The term lockdown has been used in several countries as an effort to prevent the spread of Corona Virus. According to The the Economic Times, "A lockdown is an emergency protocol that prevents people from leaving a given area. A full lockdown will mean you must stay where you are and not exit or enter a building or the given area." The term lockdown or emergency protocol which prevents people from leaving a certain area so that a person must stay where he is and not leave or enter another area.[4]
Lockdown in general can be interpreted as locking access to and from an area or country. However, the term lockdown is not recognized in the laws and regulations in Indonesia. What is known is the term regional quarantine and large-scale social restrictions as regulated in Law Number 6 of 2018 concerning Health Quarantine.

Territorial quarantine is a restriction on the population in an area including the area of entrance and its contents that are suspected of being infected with a disease and / or contaminated in such a way as to prevent the possibility of spreading disease or contamination.

The quarantine is carried out for all members of the community in an area, if the laboratory confirmation results have spread of disease among community members in that area. The health quarantine official is obliged to provide an explanation to the community in the local area before implementing the area quarantine. The quarantined area is then given a quarantine line and is continuously guarded by the Health Quarantine Officials and the Indonesian National Police who are outside the quarantine area.

Community members who are self-quarantined are not allowed to enter the quarantine area. If during the area quarantine period it turns out that one or more members in the area is suffering from an ongoing public health emergency, then isolation measures are taken and immediately referred to the hospital.

In addition to regional quarantine, large-scale social restrictions are also known, namely limiting certain activities of residents in an area suspected of being infected with a disease and / or contamination in such a way as to prevent the possibility of spreading disease or contamination. These restrictions include at least:

a school and work vacation;

$\mathrm{b}$ restrictions on religious activities; and / or

c limitation of activities in public places or facilities.

School and work vacations as well as restrictions on religious activities must take into account the educational needs, work productivity and worship of the population. Restrictions on activities in public places or public facilities are carried out by taking into account the fulfillment of the basic needs of the population. 


\subsubsection{Principles of the rule of law}

The idea of a rule of law existed long before the Revolution of 1688 in England, but only reappeared in the XVII century and became popular in the XIX century. The history of the emergence of thoughts or ideals of the rule of law itself is actually very old, much older than the age of state science or state science. The idea of a rule of law was first put forward by Plato and then that thought was emphasized by Aristoteles.[5]

In the Western tradition, there are two types of rule of law, namely rechtsstaat which developed in the legal tradition of Continental Europe and the rule of Law which developed in the Anglo Saxon legal tradition. In general, rechtsstaat developed from the concept of "Liberaal Rechtsstaat" (Liberal Law State) in the 19th century which saw that the role of the state must be reduced to protect and promote personal freedom and private property (grondrechten) which was structurally carried out by separation of powers (scheiding van machten). ). In its development, the concept of liberaal rechtsstaat is moving towards "Formaal Rechtsstaat" (Formal Law State) in line with the rise of legal positivism thinking and codification of law which emphasizes the principle of legality (wetmatigeheid van bestuur) and separation of administrative courts (administratieve rechtspraak) as instruments to protect each individual from abuse of power by administrative officials. During the Weimar Republic, the concept of formal rechtsstaat developed into a totalitarian which only emphasized the principle of legality and therefore rejected the existence of judicial review (gesetz). After World War II, a new awareness emerged towards a more substantive rechtsstaat even though it retained its formal aspects which then gave birth to the concept of "Sozialen Rechtsstaat" (State of Social Law). This last concept combines the protection of fundamental rights and the role of the state which actively promotes the welfare of citizens. [6]

The rule of law is termed rechstaats or the rule of law. In Indonesia, the founding father had aspired to the establishment of a state from the beginning as a constitutional state. In the framework of the third amendment of the 1945 Constitution Article 1 paragraph (3) it is emphasized that "the Indonesian State is a State of Law". Even though it has been explicitly stated in the constitution as a state based on law, the blueprint and macro design for the elaboration of the idea of a rule of law have not yet been formulated comprehensively.
The idea of a rule of law actually has long been developed by philosophers from ancient Greece, Plato, in his books "the Statesman" and "the Law", stating that the rule of law is the second best form (the second best) to prevent the decline of one's power is government. by law. The concept of a modern rule of law in Continental Europe was developed using the German term rechtsstaat "among others by Immanuel Kant, Paul Laband, Julius Stahl, Fichte, and others. Meanwhile, in the Anglo American tradition, the concept of rule of law was developed as "the Rule of Law" pioneered by A.V.Dicey.[7]

In that case, the idea of a rule of law, apart from being related to the concepts of "rechtsstaat" and "the rule of law", is also related to the concept of "nomocracy" which comes from the words "nomos" and "cratos". The word nomocracy can be compared to "demos" and "cratos" or "kratien" in a democracy. Nomos means norm, while cratos is power[8] According to Julius Stahl, the concept of rule of law which he mentioned with the term "rechtsstaat" includes four important elements, namely:

1. Protection of human rights;

2. Distribution of power;

3. Government based on law;

4. State administrative court.

While A.V.Dicey, describes three important characteristics in each rule of law which he mentions with the term "The Rule of Law", "The Rule of Law", namely:

\section{Supremacy of Law;}

2. Equality Before the Law;

3. Due Process of Law.

The four "rechtsstaat" principles developed by Julius Stahl can be combined with the three "Rule of Law" principles developed by A.V.Dicey to achieve the characteristics of a modern rule of law. Apart from that, by "The International Commission of Jurist", the principles of rule of law also include, (1) the state must comply with the law; (2) the government respects individual rights and (3) a free and impartial trial.

Professor Utrecht has distinguished distinguishes state between formal legal states or classical legal states, and material law states or modern legal states. [5] A formal rule of law concerns the definition of law which is formal and narrow, namely in the sense of written statutory 
regulations. While the second, namely Materiel's rule of law which is more up to date also includes the notion of justice in it. Therefore, Wolfgang Friedman in his book 'Law in a Changing Society' distinguishes between 'rule of law' in a formal sense, namely in the meaning of 'organized public power', and 'rule of law' in a material meaning, namely 'the rule of just law'.

This distinction is intended to emphasize that in the concept of a constitutional state, justice will not necessarily be materialized substantively, especially because people's understanding of law itself can be influenced by the flow of the meaning of formal law and can also be influenced by the flow of thought on material law. If the law is understood in a rigid and narrow manner in the meaning of statutory regulations alone, the definition of a rule of law developed is also narrow and limited and does not necessarily guarantee substantive justice. Therefore, in addition to the term 'the rule of law' by Friedman, the term 'the rule of just law' has also been developed to ensure that our understanding of 'the rule of law' includes a more essential definition of justice than simply the functioning of statutory regulations. in a narrow sense. Even if the term used remains 'the rule of law', it is this broad definition that is expected to be included in the term 'the rule of law' which is used to refer to the conception of the rule of law today.

With the existence of several principles in a rule of law put forward by Julius Stahl and AV. Decey AVDicey, one of the main principles of the rule of law can be formulated as the main pillars that support the establishment and upholding of a modern state known as the rule of law (The Rule of Law or rechtsstaat), is the protection of citizens' rights.

\subsection{The Perspective of Human Rights}

\subsubsection{Protection of Human Rights in the Rule of Law}

Protection of human rights in society at large in order to promote respect and protection of human rights is an important feature of a democratic constitutional state. Since birth, every human being has rights and obligations that are free and basic. The formation of a state and likewise the exercise of power in a state must not reduce the meaning or meaning of freedom and human rights. Therefore, the existence of protection and respect for human rights is a very important pillar and every country is known as a rule of law. if in a country, human rights are neglected or deliberately violated and the suffering they cause cannot be dealt with fairly, then the country concerned cannot be called a rule of law in the true sense.[9]

Muhammad Yamin, stated that humans are born for true and complete freedom. Yamin considers that the chains that hold people back need to be broken so that differences are lost and equality is born. Thus, human rights are an ideal conception that must be formulated in the 1945 Constitution. The goal of establishing the Republic of Indonesia as a country that aspires to be a state of law and a nation-state, namely realizing four constitutional terms: happiness, prosperity, peace and independence.[10]

Amnesty International Indonesia noted that at least four human rights were affected by the global Covid-19 pandemic.[11]

\section{1). Right to Health:}

Article 12 (2) letter d International Covenant on Economic, Social and Cultural Rights (ICESCR) and Paragraph 12 (b) General Comment No. 14 on Article 12 of the ICESCR, which Indonesia has ratified through Law no. 11 of 2005, the state is obliged to make efforts to improve all aspects of environmental and industrial health, prevention, treatment and control of all infectious, endemic and other occupational diseases, and the creation of conditions which will ensure all medical care and attention. also guaranteed in Article 4 of Law no. 36 of 2009 concerning Health (Health Law) and Article 9 (3) of Law no. 39 of 1999 concerning Human Rights.

According to Article 55 of Law no. 24 of 2007 concerning Disaster Management, vulnerable groups include the elderly; baby; toddler; children; pregnant or nursing mothers and persons with disabilities.

\section{2). Right to Information}

The next human right affected in the midst of the Covid-19 outbreak is the right to information. In article 19 (2) of the International Covenant on Civil and Political Rights (ICCPR) and Paragraph 18 General Comment No. 34 to Article 19 of the ICCPR, the state is obliged to guarantee the right of everyone to seek and receive information, including information held by public bodies.

Not only that, the state is also obliged to guarantee accessibility to health information in accordance with article 12 (1) ICESCR and Paragraph 12 (b) General Comment No. 14 against Article 12 of the ICESCR. 
Information that can threaten the lives of many people, including information related to epidemics and epidemics, must also be published by the competent public body, in accordance with article 12 of Information Commission Regulation No. 1 of 2010 concerning Public Information Service Standards. In fact, if we look at article 154 (1) of the Health Law, the Government has an obligation to determine and announce the types and spread of diseases that have the potential to be infectious and / or spread in a short time, as well as mention areas that can be sources of transmission.

This information disclosure is important and needed by all levels of society, especially by health workers who are at the forefront of handling outbreaks. Delays and low transparency of information related to handling Covid-19 can endanger health, because the public and health workers are unable to take maximum preventive steps.

\section{3). Right to Privacy}

The Covid-19 outbreak also threatens the right to privacy. In a number of media reports, the first two patients who tested positive for corona felt depressed because of the massive media coverage of their place of residence which was conveyed by public officials. Not to mention, the impact of this news also affects their immediate environment, such as family, friends and neighbors. In fact, Article 17 of the ICCPR and Law No. 14 of 2008 on Freedom of Information have guaranteed information and personal rights. Exceptions to be opened can be granted if it is related to a person's history, condition of family members, physical and psychological health care. So, open disclosure of the identity of a corona sufferer is classified as a violation.

\section{4). Right to Work}

With the implementation of Large-Scale Social Restrictions (PSBB) with a policy of social distancing and work from home, workers in the formal to informal sectors, from home industry workers to micro, small and medium enterprises (MSMEs) ), so that casual daily workers and other low-income workers are prone to the risk of wage cuts, denial of leave rights, being laid off without wages, and termination of employment (PHK).

If the company chooses to cut leave for workers who do not enter as a means of controlling Covid19 , the Government is obliged to ensure that the company continues to pay workers' wages, in accordance with Paragraph 41 General Comment No. 23 of 2016 regarding the right to work. Workers who experience reduced income due to illness also have the right to access benefits (cash and non-cash), which include at least health, water and sanitation services, and food in accordance with paragraph 2 and paragraph 59 of General Comment No. 19 of 2007 regarding the Right to Social Security.

\subsubsection{Lockdown Policy in Human Rights Protection}

Regional quarantine and social restrictions are established as an effort to limit the spread of diseases that cause health emergencies. The state of emergency needs to be determined in advance by the central government, as regulated in Article 10 paragraph (1) of Law 6/2018 below:

The Central Government determines and revokes Public Health Emergencies. Before determining this status, the government must first determine the types of diseases and risk factors that can cause a public health emergency.

After it is determined that a public health emergency exists, the central government, represented by the Minister of Health, has the authority to determine regional quarantine and largescale social restrictions. The status of the corona outbreak itself is currently determined by the government through the National Disaster Management Agency (BNPB) as a "Certain Disease Outbreak Disaster Conditions".

Health quarantine must respect human rights and the basics of freedom of a person. This is clearly stated in the Considering Section letter point $\mathrm{c}$ of Law 6/2018 as follows:

that as part of the world community, Indonesia is committed to making efforts to prevent public health emergencies that are troubling the world as mandated in international regulations in the field of health, and in carrying out this mandate Indonesia must fully respect the dignity, human rights, the basics of freedom of a person., and its universal application;

In addition, Article 2 letter f of Law 6/2018 has explained that health quarantine must be implemented based on the principle of public interest. What is meant by the principle of "public interest" is that in the administration of health quarantine, the public interest must be prioritized over the interests of individuals or certain groups. The existence of health quarantine will certainly limit the movement of the community. This is also in accordance with Article 73 of Law Number 39 
Year 1999 concerning Human Rights, which states that: Rights and freedoms regulated in this Law can only be limited by and based on law, solely to guarantee recognition and respect for human rights and basic freedoms of others, morality, public order, and the interests of the nation.

In the case of a lockdown policy or restrictions on movement made by the government, according to Nan D. Hunter, that the success or failure of health quarantine, must be balanced with guarantees of other community rights. As he said, the effectiveness of modem quarantine relies on the public's willingness to remain at home voluntarily to avoid exposure and possible transmission of an infectious disease. Public opinion poll data document that a common popular concern about quarantine during an infectious disease outbreak pertains to how persons would maintain themselves and their families if they could not work. 47 A poll commissioned by the CDC found that seventy-six percent of respondents believed that they would have serious financial problems if they had to miss work.[12]

The principle of income replacement for persons who cannot work during a health emergency is well established in the abstract. The ILO's 1969 Recommendation provided for income replacement to individuals under quarantine. All of the countries most affected by the SARS outbreak in 2003 adopted laws that provided some form of monetary compensation to persons who were under quarantine or who had been advised to remain at home.

One model for income replacement in the existing American law is the unemployment compensation benefits system. As a threshold matter, however, individuals who did not lose their jobs, but who received unpaid leave, would not qualify for unemployment compensation. These individuals would be protected in the sense that they would have a job to return to when they became able to work again, and their membership in a workplace health insurance plan, if their employer sponsored one, would continue. 66 But they could not receive unemployment benefits.

In Indonesia, the provision of compensation or allowances in implementing lockdown policies or closure of regional borders or large-scale social restrictions has been regulated in Law 6/2018, by mandating that the government is responsible for protecting public health from disease and / or potential public health risk factors. causing health emergencies through the implementation of community quarantine. (Article 4 of Law 6/2018. During the area quarantine, the basic necessities of life for people and food for livestock in the quarantine area are the responsibility of the central government. (Article 55 paragraph (1) of Law 6/2018)

Then, Article 8 of Law 6/2018 emphasizes that everyone also has the right to get basic health services according to medical needs, food needs, and other daily needs during quarantine. What is meant by "other daily necessities of life" include the needs for clothes and toiletries, washing and defecating. (Elucidation of Article 8 of Law 6/2018). In addition, everyone has the right to receive equal treatment in the administration of health quarantine. (Article 7 of Law 6/2018)

\section{CONCLUSION}

Based on the above discussion, it is clear that the lockdown policy is a form of human rights violation because it restricts movement and reduces other rights. However, the lockdown policy can be exempted by the regulation of Law No.6 of 2018 concerning on Health Quarantine, which states that the lockdown policy is carried out to ensure the health of all Indonesian citizens so as not to be infected with the corona virus. Thus, it cannot be categorized as a violation of human rights.

However, in order for the lockdown policy to uphold the principles of human rights as reflected in the principles of a modern rule of law, the government as state administrator must enforce the provisions in Law No.6 of 2018, by providing compensation for both food and medical needs as well as relief. living expenses incurred due to the lockdown policy by the government.

\section{REFERENCES}

[1] Andryan, "Harmonisasi Pemerintah Pusat dengan Daerah Sebagai Efektifitas Sistem Pemerintahan," J. Legis. Indones., vol. 16, no. 4, pp. 419-432, 2020.

[2] R. Wadi, "Konstitusionalitas Pemerintah Daerah dalam Menetapkan Kebijakan Lockdown Pada Penanganan Covid-19," J. Sos. Budaya Syar'i FSH UIN Syarif Hidayatullah Jakarta, vol. 7, no. 7, pp. 614624, 2020.

[3] AG. Subarsono, Analisis Kebijakan Publik, Cetakan IV. Yogyakarta: Pustaka Pelajar, 2009.

[4] P. C. dan L. dalam D. Hukum, "No Title," 
Kompas,

http://nasional.kompas.com/read/2020/03/2

7/19512871/pandemi-corona-dan-

lockdown-dalam-diskursus-

hukum?page $=$ all.

[5] N. Huda, Negara Hukum, Demokrasi dan Judicial Review, Pertama. Yogyakarta: UII Press, 2005.

[6] A. FA, "Negara Hukum Indonesia," J. Huk. Ius Quia Iustum, vol. 19, no. 4, p. 64, 2012.

[7] J. Asshiddiqie, Konstitusi dan Konstitusionalisme Indonesia, Edisi Revi. Jakarta: Konstitusi Press, 2005.

[8] J. Asshiddiqie, Menuju Negara Hukum Yang Demokratis. Jakarta: PT. Bhuana Ilmu Populer, 2009.

[9] Utrecht, Pengantar Hukum Administrasi Negara Indonesia. Jakarta, 1962.

[10] PSHK, “Komisi Negara," J. Huk. Jentera, vol. 12, no. 3, p. 134, 2006.

[11] "Covid dan Hak Asasi Manusia," 2020. http://www.amnesty.id/covid-19-dan-hakasasi-manusia/.

[12] N. D. Hunter, "Public Private Health Law: Multiple Directions in Public Health," $J$. Health Care Law Policy, vol. 10, no. 89, pp. 114-116, 2010. 